\title{
Changes in IGFs in cardiac tissue following myocardial infarction
}

\author{
K G Matthews, G P Devlin ${ }^{1}$, J V Conaglen ${ }^{1}$, S P Stuart, \\ W Mervyn Aitken and J J Bass
}

Growth Physiology Department, AgResearch Ruakura, East Street, Hamilton, New Zealand

${ }^{1}$ Waikato Academic Division, Faculty of Medicine, University of Auckland, Bryant Education Centre, Waikato Hospital, Hamilton, New Zealand

(Requests for offprints should be addressed to K G Matthews, Growth Physiology Department, AgResearch Ruakura, Private Bag 3123, East Street, Hamilton, New Zealand; Email: matthewsk@agresearch.cri.nz)

\begin{abstract}
We have studied changes in the IGF axis in an ovine model of myocardial infarction (MI), in order to determine the relationship between time-based changes in postinfarct myocardium and IGF levels. IGF localization was studied by immunocytochemistry, production by in situ hybridization, and specific binding by radioligand studies.

In surviving tissue, IGF-I peptide localized to cardiomyocytes, with strongest immunostaining at 1 and 2 days post-infarct in the immediate border area adjoining the infarct, where IGF-I mRNA also increased, reaching a maximum at 2 days. Binding of radiolabelled IGF-I in surviving tissue was initially lower than that seen in cardiomyocytes in control myocardium, subsequently increasing to become significantly greater by 6 days post-infarct.

In necrotic tissue, IGF-I peptide was still detectable in cardiomyocytes at 0.5 days post-infarct, but had cleared from this area by 1 day, becoming detectable again at 6 days post-infarct in macrophages and fibroblasts infiltrating the repair zone. IGF-I mRNA was not detected in necrotic tissue until 6 days, when probe hybridized to macrophages and fibroblasts. Within the necrotic zone,
\end{abstract}

high levels of radiolabelled IGF-I binding to a combination of receptors and binding proteins were observed in cardiomyocytes in islands of viable tissue located close to the border.

Weak immunostaining for IGF-II was observed in cardiomyocytes of the surviving tissue. IGF-II mRNA was not detected in either surviving or necrotic areas. Binding of radiolabelled IGF-II was predominantly to macrophages in both surviving and infarct areas, although as with IGF-I, high levels of binding of radiolabelled IGF-II to a combination of receptors and binding proteins were observed in islands of viable tissue close to the border within the necrotic area.

We conclude that, following MI, surviving cardiomyocytes at the infarct border show marked changes in IGF-I localization, production, and specific binding, indicating that the IGF axis is directly involved in post-infarct events, possibly in the maintenance of cardiac function by the induction of hypertrophy and in cell survival by decreasing apoptotic cell death, which has been demonstrated in other cell types.

Journal of Endocrinology (1999) 163, 433-445

\section{Introduction}

Cardiomyocytes exit from the cell cycle shortly after birth and become terminally differentiated ( $\mathrm{Li}$ et al. 1996). Therefore, following loss of cardiac muscle tissue due to myocardial infarction (MI), viable cardiomyocytes in the peri-infarct zone are unable to re-enter the cell cycle and thus cannot replicate to regenerate the lost tissue. Instead, lost tissue is replaced by the deposition of scar tissue in the damaged region (Anversa et al. 1986) and by hypertrophy of the viable cardiomyocytes bordering the damaged area (Olivetti et al. 1991) leading, in the case of large infarcts, to dysfunction of the chamber wall and eventual pump failure. Insulin-like growth factor-I (IGF-I) has been shown to induce hypertrophy in cultured rat cardiomyocytes (Ito et al. 1993) and it has been demonstrated that
IGF-I mRNA increases co-ordinately with the onset of left ventricular pressure overload and early in the development of the resulting hypertrophy (Donahue et al. 1994). Subsequently, IGF-I mRNA levels normalize once the hypertrophic response is established (Donahue et al. 1994), despite the continuing overload.

It has been recognized for many years that occlusion of a coronary artery results in ischaemic cell death in the myocardium with subsequent necrosis (Mallory et al. 1939). Recently, it has been shown that programmed cell death, or apoptosis, also contributes significantly to cell death in the necrotic area (Kajstura et al. 1996) and in the surviving portion of the heart (Olivetti et al. 1994, Cheng et al. 1996a). The IGF-I receptor (D'Mello et al. 1993, Resnicoff et al. 1995, D'Ambrosio et al. 1997) and its ligand (Rodriguez-Tarduchy et al. 1992) have been shown 
to inhibit death by apoptosis in many cell types. Specifically, in the myocardium, IGF-I has been shown to protect cardiomyocytes in the surviving tissue from apoptosis following MI (Li et al. 1997).

It has been postulated that the apoptosis and hypertrophy which follow the initiation of pressure overload in the heart are related events, with hypertrophy initiated by a wave of apoptosis in cardiomyocytes (Teiger et al. 1996). Because both events may be modulated by IGF-I, we have studied the IGF axis post-infarct, when work overload occurs, particularly in the cardiomyocytes adjacent to the infarct border. Previous studies which have examined the response of IGF-I and its receptor to the occlusion (Reiss et al. 1994a,b, Cheng et al. 1996b) or the restriction (Reiss et al. 1993) of a coronary artery have done so in vitro using cardiomyocytes isolated from post-infarct ventricular myocardium, and thus deprived of the modulating influence of non-cardiomyocytes and the extracellular matrix (Harada et al. 1997). Such cells are also removed from the stress which initiates the changes reported. Others have documented in vivo only the location of IGF-I peptide in the myocardium following MI (Krishnamurthi et al. 1997). The present study has undertaken a comprehensive evaluation in vivo of the IGF axis following induced MI in sheep heart, in order to determine the relationship between time-based changes in the myocardium and IGF levels.

\section{Materials and Methods}

\section{Animal model}

A group of 25 three-year-old sheep, weighing 55-75 kg, were acclimated to indoor living on a pellet diet. Food was withheld $24 \mathrm{~h}$ prior to surgery, but water was freely available. Animals were anaesthetized and maintained under anaesthesia with subcutaneous ketamine hydrochloride $(2 \mathrm{mg} / \mathrm{kg})$ and xylazine $(0 \cdot 4 \mathrm{mg} / \mathrm{kg})$. Intramuscular buprenorphine $(0.3 \mathrm{mg})$ was given for analgesia.

Monitoring electrodes ( $3 \mathrm{M}$, St Paul, MN, USA) were attached to shaven areas of the thoracic wall and monitor leads connected to a Burdick EK-SA (Milton, WI, USA) electrocardiograph.

The femoral artery was exposed and an introducer sheath (Terumo, Tokyo, Japan) inserted. Under fluoroscopic guidance, a 0.038 inch J guide wire (Cook, Bloomington, IN, USA) was advanced over the aortic arch and into the aortic sinus, followed by an 8 Fr Amplatz left (AL1) guide catheter (Cook). The guide wire was then withdrawn and the guide catheter manoeuvred into the left coronary artery. An 0.018 inch guide wire (Cook), followed by a $3 \mathrm{Fr}$ infusion catheter with radiopaque tip (Cook) were then selectively introduced into the distal left anterior descending coronary artery.

The guide wire was withdrawn and $0 \cdot 2 \mathrm{ml}$ of a mixture comprising $0 \cdot 2 \mathrm{mg}$ sterile gel foam (Upjohn, Kalamazoo, MI, USA) suspended in $5 \mathrm{ml}$ saline was injected into the infusion catheter and flushed through with $5 \mathrm{ml}$ contrast medium (Omnipaque, Oslo, Norway). On observing ST elevation, the infusion and guide catheters were withdrawn. Two millilitres Duplocillin long-acting penicillin antibiotic (Intervet, Boxmeer, Holland) were given on completion of surgery. Three animals were shamoperated. In these animals, the catheter was positioned in the aortic sinus and then withdrawn.

All animal manipulations were approved by the AgResearch Ruakura Animal Ethics Committee.

\section{Tissue sampling}

Seven animals did not survive the induction of MI. Surviving animals were slaughtered in groups of three at $0 \cdot 5,1,2,6$ and 12 days post-infarct. Three sham-operated controls were slaughtered 12 days post-operatively. Following slaughter, the hearts were excised and multiple tissue samples taken across the border of the infarct zone, to include both peri-infarct and infarct tissue. Tissue was either snap-frozen in liquid nitrogen and subsequently stored at $-75^{\circ} \mathrm{C}$, or fixed in $4 \%$ neutral buffered formalin for $24 \mathrm{~h}$ and processed to wax. Sections were cut from wax-embedded tissue and stained with haematoxylin and eosin (H\&E), and from frozen tissue and stained with toluidene blue. Sections were then examined under the microscope and sample blocks which did not include a clearly demarcated infarct border were rejected. Subsequently, 20 serial sections were cut from each waxembedded block for experimental purposes, whilst frozen tissue was cut as required.

Throughout this study, tissue location with respect to the border between necrotic and surviving myocardium will be described as follows: necrotic proximal - necrotic tissue $0.5 \mathrm{~mm}$ or less from the infarct border; necrotic distal - necrotic tissue $0.5 \mathrm{~mm}$ or more from the infarct border; viable proximal - viable tissue $0.5 \mathrm{~mm}$ or less from the infarct border; viable distal - viable tissue $0.5 \mathrm{~mm}$ or more from the infarct border.

\section{Descriptive histology}

Seven-micron transmural sections were cut from waxembedded tissue, mounted on microscope slides and stained with H\&E for light microscopic examination.

\section{Immunocytochemistry}

Incubations were carried out with a number of polyclonal antisera. The recombinant human (rh) IGF-I (1:1000) and rhIGF-II (1:150) antibodies were purchased from Gropep (Adelaide, SA, Australia). Rabbit polyclonal antibodies raised in our laboratory against recombinant ovine IGFbinding protein (IGFBP) $-2,-3$ and -4 were used at 1:200. Specificity of immunoreactivity was checked with a 
number of control incubations: (1) with non-immunized rabbit serum (Dako, Carpinteria, CA, USA), diluted 1:1000 (IGF-I), 1:150 (IGF-II) or 1:200 (IGFBP) in 1\% PBS/BSA, (2) with antibody diluent minus primary antibody, (3) with antibody diluent minus secondary antibody and (4) (IGF-I and -II only) with primary antibody pre-adsorbed by its respective antigen on a cyanogen bromide activated Sepharose column (Pharmacia, Uppsala, Sweden).

Seven-micron sections were cut from wax-embedded tissue, mounted on aminoalkylsilane-treated slides, and baked overnight at $37^{\circ} \mathrm{C}$. After de-paraffinization in xylene, sections were rehydrated in descending concentrations of ethanol, followed by $3 \mathrm{~min}$ in PBS, $\mathrm{pH} 7 \cdot 2$. Endogenous peroxidase activity was quenched by immersion for $15 \mathrm{~min}$ at room temperature (RT) in PBS containing 1\% (v/v) hydrogen peroxide. Sections were subsequently washed twice in PBS for $5 \mathrm{~min}$. To minimize non-specific antibody binding, sections were incubated with 5\% (w/v) BSA (Sigma Chemical Co., St Louis, $\mathrm{MO}$, USA) for $30 \mathrm{~min}$ at RT.

Primary incubation Primary incubations were carried out in a humidified chamber for $1 \mathrm{~h}$ at RT and were terminated by three washes in PBS, each for 10 min.

Secondary incubation A biotinylated donkey antirabbit secondary antibody (Amersham International, Amersham, Bucks, UK), diluted 1:200 in 1\% PBS/BSA was applied and sections incubated in a humidified chamber for $2 \mathrm{~h}$, followed by three washes in PBS, each for $5 \mathrm{~min}$.

Tertiary incubation A streptavidin-biotinylated horseradish peroxidase complex (Amersham), diluted 1:100 in $1 \% \mathrm{PBS} / \mathrm{BSA}$, was applied and sections incubated for $2 \mathrm{~h}$ in a humidified chamber at RT, followed by three washes in PBS, each for $5 \mathrm{~min}$.

Visualization Antibody-bound peroxidase was visualized with diaminobenzidine tetrahydrochloride (Gibco, New York, NY, USA), in 0.05 M Tris- $\mathrm{HCl}$ buffer, $\mathrm{pH}$ $7 \cdot 6$, at a working concentration of $0.5 \mathrm{mg} / \mathrm{ml}$, applied to the sections for $3 \mathrm{~min}$. The reaction was stopped by washing in PBS for 5 min.

Sections were then washed for $10 \mathrm{~min}$ in ultra-pure deionized water from a Milli-Q plus system (Millipore S.A., Molsheim, France), counterstained with Carrazi's haematoxylin and mounted.

\section{Receptor binding studies}

Tissue Frozen tissue, stored at $-75^{\circ} \mathrm{C}$ was equilibrated to $-20{ }^{\circ} \mathrm{C}, 24 \mathrm{~h}$ prior to cutting $8 \mu \mathrm{m}$ sections in a cryostat (Leitz, Wetzler, Germany). Sections were thawmounted in pairs onto gelatine chrome-alum coated microscope slides.
Incubations Incubations were carried out using the method described by Palacios \& Dietl (1987) as adapted by Elliott et al. (1992), using iodinated rhIGF-I (Ciba-Geigy, Summit, NY, USA), or iodinated rhIGF-II (Eli Lilly, Indianapolis, IN, USA) at 20000 c.p.m./ $\mu$ l. One section of each pair on the slide was incubated with ${ }^{125}$ I-IGF alone to determine total binding, the other was incubated with

${ }^{125}$ I-IGF and competing unlabelled hormone. Unlabelled hormones competing with ${ }^{125}$ I-IGF-I were: rhIGF-I at $1 \mu \mathrm{g} / \mathrm{ml}$, rhIGF-II at $1 \mu \mathrm{g} / \mathrm{ml}$, des(1-3) IGF-I at $1 \mu \mathrm{g} / \mathrm{ml}$, bovine insulin at $250 \mu \mathrm{g} / \mathrm{ml}$ and bovine insulin at $10 \mathrm{ng} /$ $\mathrm{ml}$. Unlabelled hormones competing with labelled IGF-II were: rhIGF-II at $1 \mu \mathrm{g} / \mathrm{ml}$, rhIGF-I at $1 \mu \mathrm{g} / \mathrm{ml}$, des(1-6) IGF-II at $1 \mu \mathrm{g} / \mathrm{ml}$, bovine insulin at $250 \mu \mathrm{g} / \mathrm{ml}$ and bovine insulin at $10 \mathrm{ng} / \mathrm{ml}$. Binding that remained after incubation with unlabelled homologous IGF was termed non-specific binding. Specific binding, as presented in Results, was the difference between total binding and non-specific binding. Non-specific binding in the case of des IGF arises because des IGF does not bind to IGFBPs, thus permitting binding of ${ }^{125}$ I-IGF to binding proteins where they are present.

Autoradiography The dried sections were apposed to X-Omat AR5 film (Eastman Kodak, Rochester, NY, USA) for 3 days and the developed film used to estimate the exposure period for the sections under emulsion. Sections were coated with NTB-2 emulsion (Eastman Kodak), dried overnight with silica desiccant, then exposed for 10 days (IGF-I) or 6 days (IGF-II) at $4{ }^{\circ} \mathrm{C}$.

\section{In situ hybridization}

Probes IGF-I and IGF-II sense and antisense cRNA probes were radiolabelled with ${ }^{35} \mathrm{~S}$ during in vitro transcription from the SP6 and T7 promoters. The IGF-I probe was transcribed from a $203 \mathrm{bp}$ Sau3A sequence containing the coding region for IGF-I D and $\mathrm{E}$ domains and $40 \mathrm{bp}$ of the $3^{\prime}$ non-coding sequence, cloned into the BamHI site of a pGEM3 vector, which allowed for synthesis of both sense and antisense probes, the former being used as a control for non-specific hybridization. The IGF-II sense and antisense probes were transcribed from a $534 \mathrm{bp}$ Pst1/Hinf1 sequence containing the coding region for the signal peptide, mature IGF-II, and part of the $\mathrm{E}$ domain, cloned into a pGEM3 vector. Ovine kidney, 6 weeks post-natal, was used as a positive tissue control for IGF-II, and adult ovine liver as a positive tissue control for IGF-I

In situ hybridization was conducted according to a method described by Parry et al. (1995).

Autoradiography The dried sections were apposed to $\mathrm{X}$-Omat AR 5 film for 3 days and the developed film used 
to estimate the exposure period for the sections under emulsion. Sections were coated with NTB-2 emulsion (Eastman Kodak), dried overnight with silica desiccant, then exposed for 48 days (IGF-I) or 42 days (IGF-II) at $4{ }^{\circ} \mathrm{C}$.

\section{Ligand blot}

Extraction Protein extraction was carried out using a modified method of D'Ercole et al. (1984). Frozen cardiac tissue was homogenized in cold $1 \mathrm{M}$ acetic acid, using $5 \mathrm{ml}$ acid/g tissue. The homogenate was incubated on ice for $2 \mathrm{~h}$, then centrifuged at $40000 \mathrm{~g}$ for $30 \mathrm{~min}$ at $4{ }^{\circ} \mathrm{C}$. The supernatant was separated and retained. The precipitate was then extracted again with fresh acetic acid. The combined supernatants were frozen at $-75{ }^{\circ} \mathrm{C}$, lyophilized to dryness, and reconstituted in $0.05 \mathrm{M}$ Tris- $\mathrm{HCl}$ buffer, $\mathrm{pH} 7 \cdot 6$, at a ratio of $2 \mathrm{ml}$ buffer to $1 \mathrm{~g}$ original tissue. Any residual particulate matter was removed by centrifugation at $600 \mathrm{~g}$ for $10 \mathrm{~min}$. Tissue extracts from control tissue and from tissue taken across the infarct border at $0 \cdot 5,1,2,6$ and 12 days post-infarct were prepared in this manner.

Electrophoresis Total protein concentration of the cardiac tissue extracts was determined by the Bradford assay on a U-2001 spectrophotometer (Hitachi, Tokyo, Japan) to be in the order of $4 \mu \mathrm{g} / \mu \mathrm{l}$. Twenty microlitres of each extract and $5 \mu$ of $5 \times$ sample treatment buffer were run on a $12 \%$ polyacrylamide gel with $10 \mu \mathrm{l}$ of molecular mass markers (Gibco-BRL, Grand Island, NY, USA). Samples and molecular mass markers were then electrophoresed for $1 \mathrm{~h}$ at $150 \mathrm{~V}$ in a Bio-Rad (Richmond, CA, USA) Mini-Protean II electrophoresis cell using the method of Hossenlopp et al. (1986).

Blotting On completion of electrophoresis, the gel was equilibrated in transfer buffer for $15 \mathrm{~min}$ and then blotted onto nitrocellulose membrane using a semi-dry transfer cell (Bio-Rad) at $4{ }^{\circ} \mathrm{C}$ for $30 \mathrm{~min}$. On completion of blotting, the membrane was air dried.

Probing The membrane was subsequently rewetted in $0 \cdot 1 \mathrm{M}$ Tris-buffered saline (TBS), $\mathrm{pH} 7 \cdot 6$, containing $3 \%$ $(\mathrm{v} / \mathrm{v})$ Nonidet P40 (BDH, Poole, Dorset, UK) for $30 \mathrm{~min}$, then blocked in $0 \cdot 1 \mathrm{M}$ TBS containing 3\% BSA (w/v) for $2 \mathrm{~h}$ at RT. Following a $10 \mathrm{~min}$ wash in TBS containing $0 \cdot 1 \%(\mathrm{v} / \mathrm{v})$ Tween 20 (Sigma-Aldrich, Castle Hill, NSW, Australia), the membrane was incubated overnight with agitation, at RT, in $20 \mathrm{ml} 0.1 \mathrm{M}$ TBS containing $1 \%$ $(\mathrm{w} / \mathrm{v})$ BSA, $0 \cdot 1 \%(\mathrm{v} / \mathrm{v})$ Tween 20 and $1 \cdot 25 \times 10^{6}$ c.p.m. iodinated IGF-II. The membrane was then washed twice in TBS $/ 0 \cdot 1 \%$ Tween 20 for $15 \mathrm{~min}$, followed by three washes for $15 \mathrm{~min}$ in TBS and air dried. The membrane was then apposed to X-Omat AR5 film in a cassette with intensifying screens for 4 days at $-75^{\circ} \mathrm{C}$.

\section{Analysis and statistics}

Analysis of IGF-I and IGF-II receptor binding and of IGF-I in situ hybridization was performed on a Macintosh IIfx computer using the public domain NIH Image program (developed at the US National Institutes of Health and available on the Internet at http:// rsb.info.nih.gov/nih-image/).

Hierarchical ANOVA of the data obtained from Image showed that the between-animal variation was similar to the within-animal variation. A combined estimate of residual variation was therefore used in the $t$-test comparison of means.

\section{Results}

Following slaughter, MI was identified in all experimental animals. From 0 5-2 days following MI, damaged myocardium was eosinophilic. Granulation tissue was apparent at 6 days following MI, and scar tissue by 12 days.

\section{Immunocytochemistry}

IGF-I In the myocardium from untreated control animals, cardiomyocytes stained positive for IGF-I, whereas interstitial cells did not.

In tissue from animals at 0.5 days following induction of MI, cardiomyocytes of the viable myocardium stained positive for IGF-I at levels similar to those in control myocardium. Interstitial cells and necrotic tissue did not stain, and there was a distinct border between necrotic and viable tissue.

At 1 and 2 days, there was an increase in the intensity of staining in cardiomyocytes in viable proximal tissue (Fig. 1), whereas staining in viable distal tissue remained similar to control levels. At 2 days, some polymorphonuclear leukocytes (PMNs) stained positive for IGF-I. At 6 days, many of the macrophages invading the infarct stained positive, as did the extracellular matrix in the infarct zone. Neither fibroblasts nor lymphocytes in the infarct zone stained positive for IGF-I. At 12 days most macrophages and some fibroblasts in the necrotic area stained positive, and the intensity of staining in the extracellular matrix increased.

IGF-II Intensity of staining for IGF-II was much weaker than that for IGF-I, although the pattern of staining in control animals, and in experimental animals at 0.5 days post-infarct, was similar. Unlike IGF-I, however, there was no increased staining in the viable proximal tissue at 1 and 2 days. Positive staining for IGF-II in the infarct extracellular matrix was only apparent at 12 days postinfarct. Infiltrating macrophages, lymphocytes, fibroblasts and PMNs remained unstained.

IGFBPs Immunocytochemistry for IGFBP-3 and -4 resulted in a low level of stain, evenly distributed in cardiomyocytes of viable distal and viable proximal tissue, 


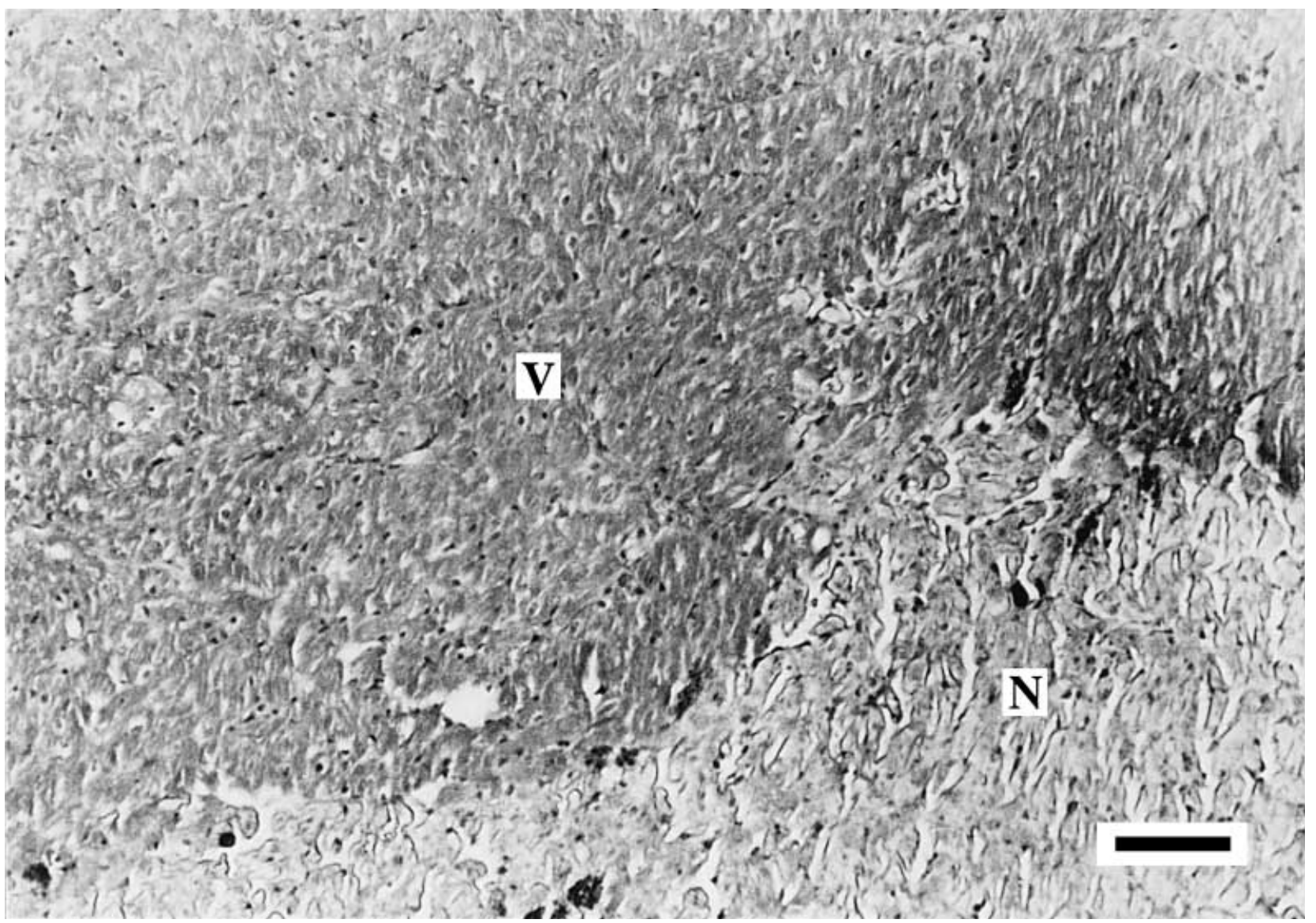

Figure 1 Photomicrograph of immunostaining for IGF-I in myocardium sampled 1 day post-infarct. Viable tissue (V) has stained, whereas necrotic $(\mathrm{N})$ tissue has not, and a sharp border is clearly seen between the two. Areas of more intense staining are seen in viable tissue at the border. Scale bar $=50 \mu \mathrm{m}$.

with no staining in necrotic areas and no increase in staining in viable proximal tissue. IGFBP-2 also exhibited no staining in the infarct area, but clearly showed increased specific staining at 1 and 2 days in cardiomyocytes located in pockets of viable tissue within the necrotic zone but close to the border (Fig. 2). An increase in stain intensity, although not of the same magnitude, was also visible in some cells of the viable proximal tissue. Viable distal tissue showed an evenly distributed staining for IGFBP-2 in cardiomyocytes, at a generally lower level than in the viable proximal tissue.

\section{In situ hybridization}

IGF-I In myocardium from control animals, a low level of IGF-I message was detected, with probe being hybridized to cardiomyocytes and showing even distribution.

In experimental animals, at 0.5 days post-infarct, in both viable proximal and viable distal tissue, levels of message were lower than levels found in controls (Fig. 3). At 1 and 2 days, message levels in cardiomyocytes in both proximal and distal viable tissue were significantly greater than control levels $(P<0 \cdot 01)$. At $0 \cdot 5,1$ and 2 days, there was no signal above background in necrotic tissue, whereas at 6 and 12 days, following phagocytic removal of necrotic cardiomyocytes, message levels in necrotic tissue increased, with probe hybridized primarily to infiltrating macrophages and also to some fibroblasts.

IGF-II IGF-II message was below the threshold of detection of our technique in both control and experimental animals.

\section{Receptor binding}

IGF-I Specific binding to cardiomyocytes in necrotic proximal tissue was significantly greater than control values at $0 \cdot 5,1$ and 2 days (Fig. 4$)$ post-infarct $(P<0 \cdot 001)$. Unlabelled IGF-I fully displaced the labelled growth factor, and there was some displacement evident by IGF-II and by the insulin at high, but not at physiological, insulin concentrations, indicating that binding was to the type 1 IGF receptor. However, at 1 and 2 days, labelled binding 


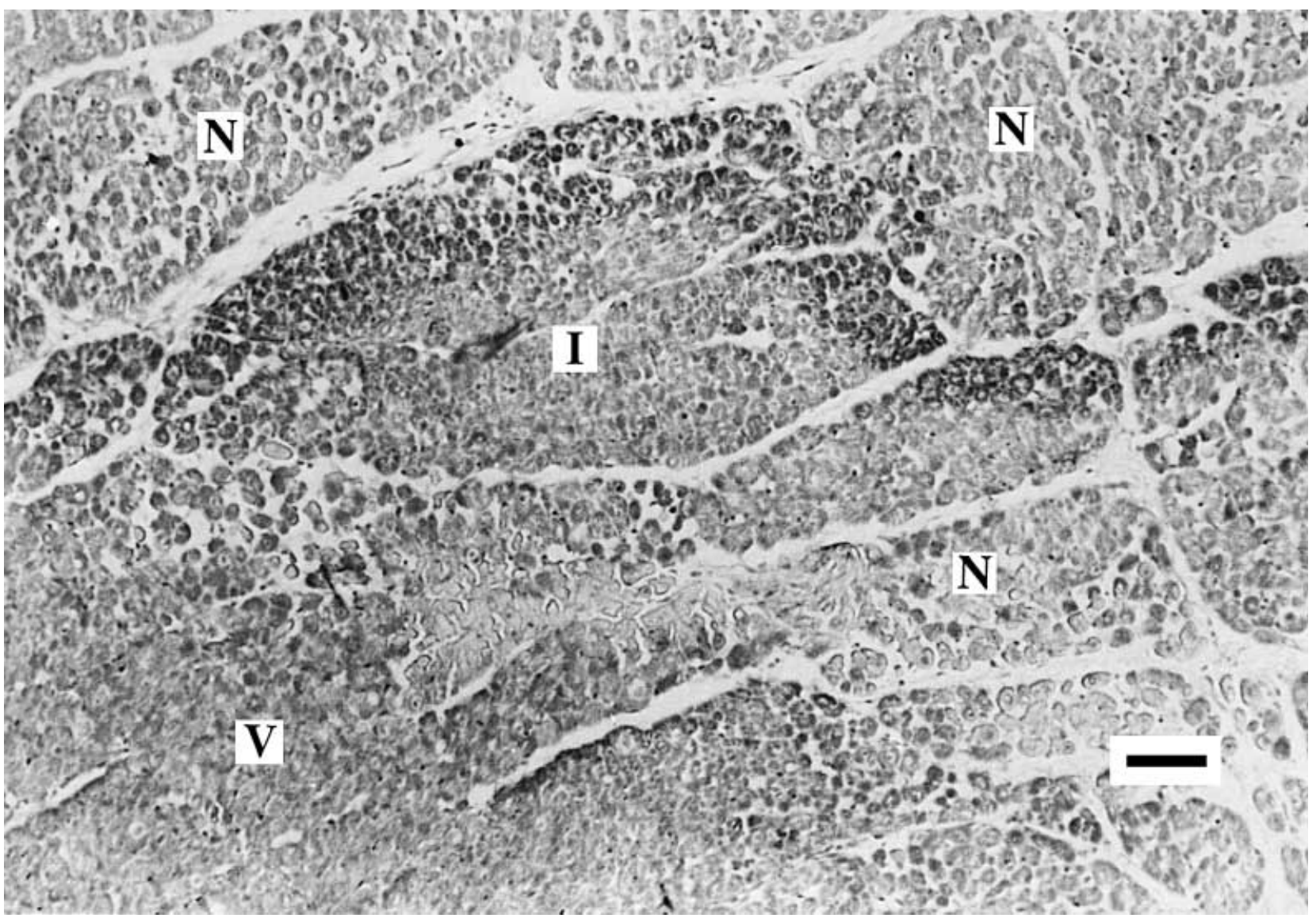

Figure 2 Photomicrograph of immunostaining for IGFBP-2 in myocardium sampled 1 day post-infarct. Strong staining is seen at the edge of an island (I) of viable tissue surrounded by necrotic tissue (N). Staining of lower intensity may be seen where the main body of viable tissue $(\mathrm{V})$ borders the necrotic. Scale bar $=50 \mu \mathrm{m}$.

in the necrotic proximal tissue was not fully displaced by competing des(1-3) IGF-I (Fig. 5, 2 days), suggesting that binding of labelled IGF-I in this area at these times represents binding to IGF-binding proteins as well as to the IGF-I receptor. Within the necrotic proximal zone, binding was significantly higher on the des(1-3) IGF-I displacement slide (Fig. 5) than on the unlabelled IGF-I displacement slide $(P<0 \cdot 01$ at 1 day, $P<0 \cdot 001$ at 2 days). The presence of binding proteins was confirmed by ligand blot (Fig. 6) and by immunocytochemistry (Fig. 2), which localized IGFBP-2 to islands of proximal viable tissue within the necrotic proximal zone. The histological origins of these islands as peninsulas of homogenous proximal viable tissue, separated by the plane of section, has been well described by Factor et al. (1978, 1981). Their presence, located within the necrotic proximal zone and showing high levels of labelled IGF-I binding to IGFBPs as well as to receptors, explains the results shown in Fig. 4 of binding apparently increasing within an area of necrotic tissue, where it might be expected to decrease. By 6 days, binding of labelled IGF-I in this area had reverted to control levels.
In necrotic distal tissue, binding of labelled IGF-I to PMNs and cardiomyocytes was greater than in control $(P<0.05)$ at 1 day, declining to become significantly lower than in control at 6 days $(P<0 \cdot 05)$ and 12 days $(P<0 \cdot 001)$, when binding appeared to be primarily to macrophages and to fibroblasts. Binding of labelled IGF-I was also observed at 1 and 2 days to PMNs in viable tissue, the cells appearing to advance in bands from the viable tissue where they exvaginated, into the necrotic tissue in large numbers, peaking at 2 days.

In both viable proximal and viable distal tissue, binding of labelled IGF-I to cardiomyocytes was initially less than control values $(P<0 \cdot 05)$, but rose to become significantly greater at 6 and 12 days $(P<0 \cdot 001)$, at which times binding appeared to be to both cardiomyocytes and tissue macrophages.

IGF-II Binding of labelled IGF-II could be displaced by unlabelled IGF-II, but not by unlabelled IGF-I, nor by either high or low concentrations of insulin, indicating that binding was to the IGF-II/mannose 6-phosphate (IGFII/M6P) receptor. Similar to IGF-I, at 1 and 2 days 


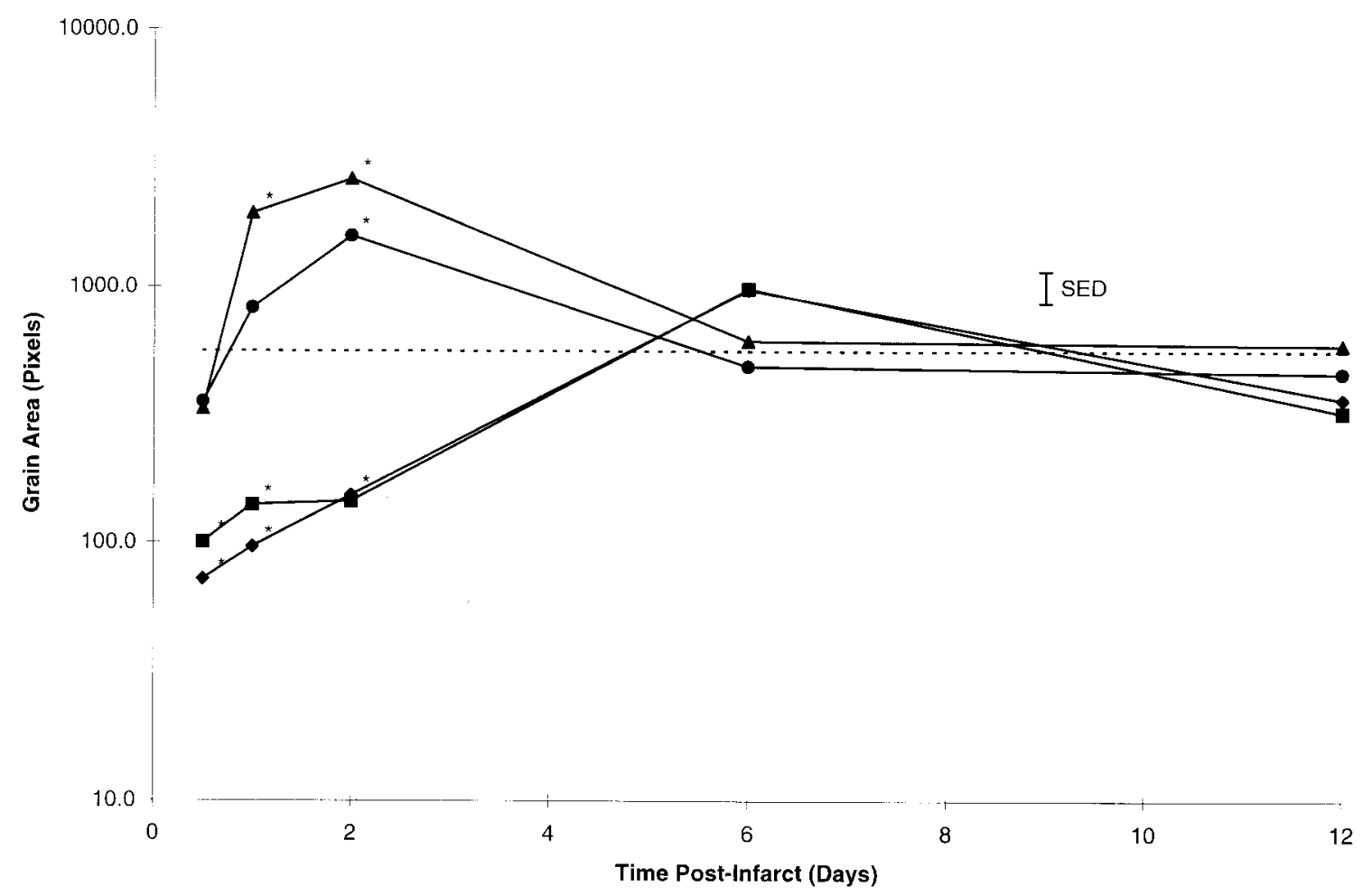

Figure 3 Graph showing changes in IGF-I message over time post-infarct. Results are presented as log mean \pm S.E. * Significantly different from control $(P<0 \cdot 05)$. $\bullet$, necrotic proximal tissue; $\mathbf{\square}$, necrotic distal tissue; $\boldsymbol{\Lambda}$, viable proximal tissue; $\boldsymbol{\bullet}$, viable distal tissue; dashed line, controls. $n=3$ at each time interval. Message is not detected in the necrotic area until 6 days post-infarct, when macrophages and fibroblasts are both present. In viable tissue, cardiomyocytes respond to MI with an increase in message production by $0 \cdot 5$ days post-infarct, returning to control levels by 6 days.

post-infarct, binding in the necrotic proximal tissue could not be fully displaced by des(1-6) IGF-II, suggesting that some specific binding in this area at these times was to IGF-binding proteins as well as to the IGF-II receptor. Binding of labelled IGF-II was significantly greater on the des(1-6) IGF-II displacement slide than on the unlabelled IGF-II displacement slide $(P<0 \cdot 001)$ at both 1 and 2 days.

IGF-II binding was elevated in necrotic tissue throughout the post-infarct period, where labelled IGF-II was frequently observed clustered over macrophage nuclei (Fig. 7).

Binding of labelled IGF-II in viable proximal tissue was greater than in control at all time intervals $(P<0 \cdot 001)$, and was seen over cardiomyocytes and clustered over tissue macrophages, whereas in viable distal tissue, binding did not differ significantly from control values.

\section{Ligand blot}

The ligand blot of IGFBPs is shown in Fig. 6 .

The doublet with a molecular mass of approximately $50 \mathrm{kDa}$ indicates the presence of IGFBP-3, the single band at $35 \mathrm{kDa}$ indicates IGFBP-2, and the low molecular mass bands of approximately $25 \mathrm{kDa}$ indicate the glycosylated and non-glycosylated forms of IGFBP-4.

Protein was extracted across the infarct border, to include both necrotic and viable tissue. It is therefore not possible to state with certainty whether changes observed are due primarily to changes in expression in the viable or in the necrotic tissue. However, the number of cells capable of expressing binding proteins in the necrotic region is restricted to the living cells present, i.e. macrophages, fibroblasts and PMNs, which are small in number in comparison with cell numbers in the viable region. It may be expected, therefore, that the ligand blot primarily represents binding proteins found in the viable peri-infarct zone. Although it is not our intention to represent the ligand blot as quantitative, we believe that it does demonstrate that changes occur in the relative abundance of the binding proteins detected. IGFBP-3 levels were relatively constant in control and infarct samples, whereas both IGFBP-2 and IGFBP-4 appear to increase following infarct, although the relative levels of both proteins vary throughout the period sampled. In the ligand blot, IGFBP-2 levels appear highest 0.5 days post-infarct, which contrasts with our immunocytochemistry findings, in which the specific localization of IGFBP-2 to the islands 

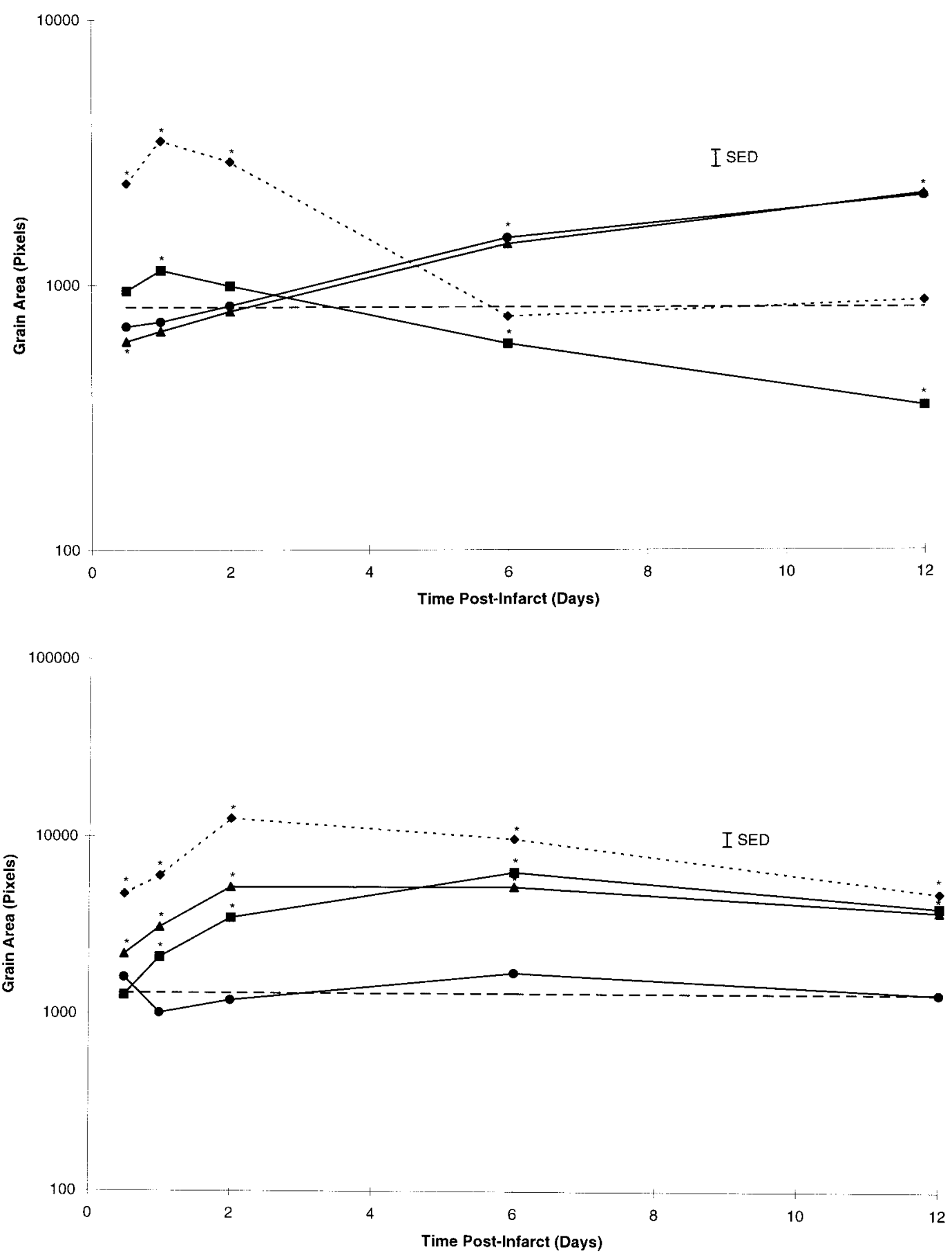

Figure 4 Graphs showing specific binding to IGF-I receptor (top) and to IGF-II/M6P receptor (bottom), plotted from total ${ }^{125}$ I-IGF binding minus homologous hormone binding. Results are presented as log mean \pm S.E. *Significantly different from control $(P<0 \cdot 05)$. $\bullet$, necrotic proximal tissue; $\boldsymbol{\square}$, necrotic distal tissue; $\boldsymbol{\Lambda}$, viable proximal tissue; -, viable distal tissue; dashed line, controls. $n=3$ at each time interval. The elevated levels of binding at 1 and 2 days in the necrotic proximal zone seen in both graphs results from binding to both receptors and IGF-binding proteins, notably IGFBP-2, in islands or peninsulas of viable tissue located close to the border, but within the necrotic zone. IGF-I binding in this area returns to control levels by 6 days, whereas IGF-II binding remains elevated due to high levels of binding clustered over macrophages from 6 days on. 


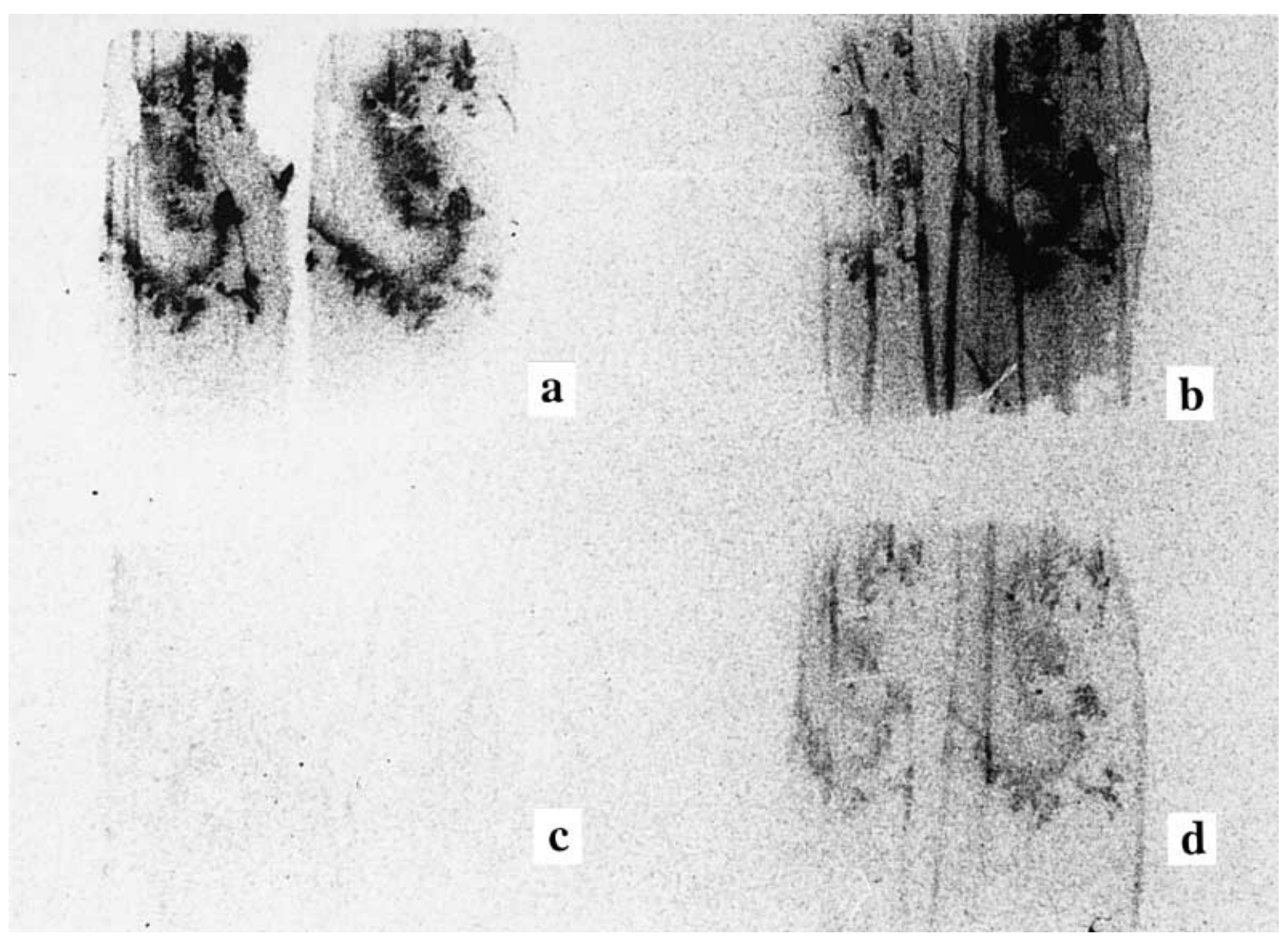

Figure 5 Autoradiograph of paired sections from cardiac tissue sampled 2 days post-infarct, showing total binding of ${ }^{125}$ I-IGF-I (a, b) displaced by unlabelled IGF-I (c) and by des(1-3) IGF-I (d). Displacement by IGF-I is complete, whereas displacement by des IGF-I is not. Des(1-3) IGF-I lacks the three amino-terminal amino acids necessary to bind IGFBPs, leading to binding of labelled IGF-I where IGFBPs are present. IGFBP-2 was detected in the border region which this autoradiograph covers, both by immunocytochemistry (Fig. 2) and by ligand blot (Fig. 6).

of viable tissue located within the necrotic zone was detected at 1 and 2 days post-infarct. However, this may be due to overall expression of the protein being higher at the 0.5 day point. IGFBP-4 levels appear to be greater than control levels at $0 \cdot 5,1$ and 12 days. Immunocytochemistry detected an overall general expression of this protein within the viable peri-infarct zone, with no specific localization.

\section{Discussion}

The ovine model which we developed for this study permitted us to permanently occlude a coronary artery with a high degree of certainty, resulting in a well-defined full-thickness MI. This enabled peri-infarct and infarct tissue to be sampled over a range of times following MI.
At 1 and 2 days post-infarct, the study demonstrated an increase in immunostaining for IGF-I in viable proximal tissue, co-located with a simultaneous increase in IGF-I mRNA production. Similarly, in rat cardiac tissue, Krishnamurthi et al. (1997) reported immunostaining for IGF-I to be $600 \%$ greater than control levels at the infarct border and $380 \%$ greater in viable tissue distant to the border at 1 day post-infarct. By analogy with skeletal muscle, these results suggest that this response may be a trigger for cardiomyocyte hypertrophy, since in rat skeletal muscle, IGF-I levels increase under load, peaking before a hypertrophic response is evident (Adams \& Haddad 1996). In the same study, IGF-I also rose in the muscles of hypophysectomized animals subjected to load, suggesting that the rise was due to an increase in local IGF-I mRNA production.

The work overload which initiates cardiac hypertrophy is accompanied by apoptotic myocyte death in the 
2
7

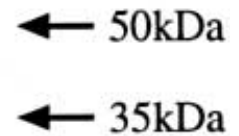

$\longleftarrow 25 \mathrm{kDa}$

Figure 6 Ligand blot of myocardial IGFBPs, from tissue sampled across the infarct border to include viable and necrotic tissue. Binding proteins were extracted from myocardium and subjected to electrophoresis on a $12 \%$ polyacrylamide gel, followed by transfer to nitrocellulose membrane as described in Materials and Methods. Lanes 2-7 were each loaded with $80 \mu \mathrm{g}$ total protein extract. Lane 1 (not shown) was loaded with $10 \mu \mathrm{l} \mathrm{Gibco-BRL} \mathrm{'Benchmark'} \mathrm{molecular} \mathrm{mass} \mathrm{markers.} \mathrm{Lanes} \mathrm{are} \mathrm{as} \mathrm{follows:} \mathrm{lane} \mathrm{2,} \mathrm{non-infarcted} \mathrm{control;}$ lane 3, 0.5 days post-infarct; lane 4, 1 day; lane 5, 2 days; lane 6, 6 days; lane 7, 12 days. The doublet with a molecular mass of approximately $50 \mathrm{kDa}$ indicates the presence of IGFBP-3, the single band at $35 \mathrm{kDa}$ indicates IGFBP-2, and the low molecular mass bands of approximately $25 \mathrm{kDa}$ indicate the glycosylated and non-glycosylated forms of IGFBP-4.

surviving myocardium (Cheng et al. 1996a). Apoptotic cell death has been reported in peri-infarct tissue, where it may be initiated by passive stretch produced by bulging of the necrotic area during ventricular contraction (Olivetti et al. 1994, Cheng et al. 1995). IGF-I has been shown to inhibit apoptosis in other cells (Rodriguez-Tarduchy et al. 1992, D'Mello et al. 1993) and may therefore have a similar role in peri-infarct tissue, where apoptotic stimuli and IGF-I levels are both greatest. While our results show IGF-I peptide levels in this area returning to control levels by 6 days, Krishnamurthi et al. (1997), using semi-quantitative immunocytochemistry, reported elevated levels up to 20 days post-infarct in rats.

In contrast to the early rise in IGF-I message, IGF-I receptor binding in surviving viable myocardium was not significantly greater than in control until 6 days postinfarct, remaining elevated at 12 days. We ascribe the lower levels of binding observed prior to 6 days to receptor downregulation, mediated by increased receptor occupancy as a result of high ligand levels (Rechler \& Nissley 1985, Venkatesan \& Davidson 1990). An alternative explanation, however, is that the binding proteins we have detected at the early time periods are modulating receptor binding (McCusker et al. 1991). Binding levels are similar in both viable proximal and viable distal tissue. Increase in IGF-I receptor numbers is known to inhibit apoptosis (Resnicoff et al. 1995, D'Ambrosio et al. 1997), and this may be one role of the receptor in surviving tissue following MI from 6 days on, when IGF-I protein levels return to control values.
At 1 and 2 days post-infarct, IGF-I receptor binding in the infarct zone was primarily to PMNs, which at 2 days exhibited levels of binding in excess of control, due primarily to the high numbers of these cells in some areas. By 6 days, when few PMNs remained, binding was lower than control levels and declined further by 12 days, being located primarily over macrophages and some fibroblasts. Macrophages and fibroblasts stained positive for IGF-I peptide, and also expressed IGF-I message. These results suggest that locally produced IGF-I in the infarct zone may be implicated in autocrine/paracrine stimulation of macrophage and fibroblast proliferation (Nagaoka et al. 1991, Ghahary et al. 1995). Macrophages (Bitterman et al. 1986) and fibroblasts (Scheven \& Hamilton 1991) are both known to produce IGF-I mRNA.

Immunostaining in viable cardiomyocytes for IGF-II was weak and did not show the increase at the border that was shown by IGF-I. IGF-II message was not detected in cardiac tissue from control or experimental animals, suggesting that locally produced IGF-II is not involved in the events which follow MI. IGF-II/M6P receptor binding, however, increased rapidly in both viable and infarct tissue, and was located primarily in clusters over macrophages. Since our results show IGF-II is not elevated post-infarct, we postulate that the IGF-II/ M6P receptor may be involved in other functions, such as the activation of latent transforming growth factor- $\beta$, which requires binding of the latent form of the peptide to the IGF-II/M6P receptor (Dennis \& Rifkin 1991). 


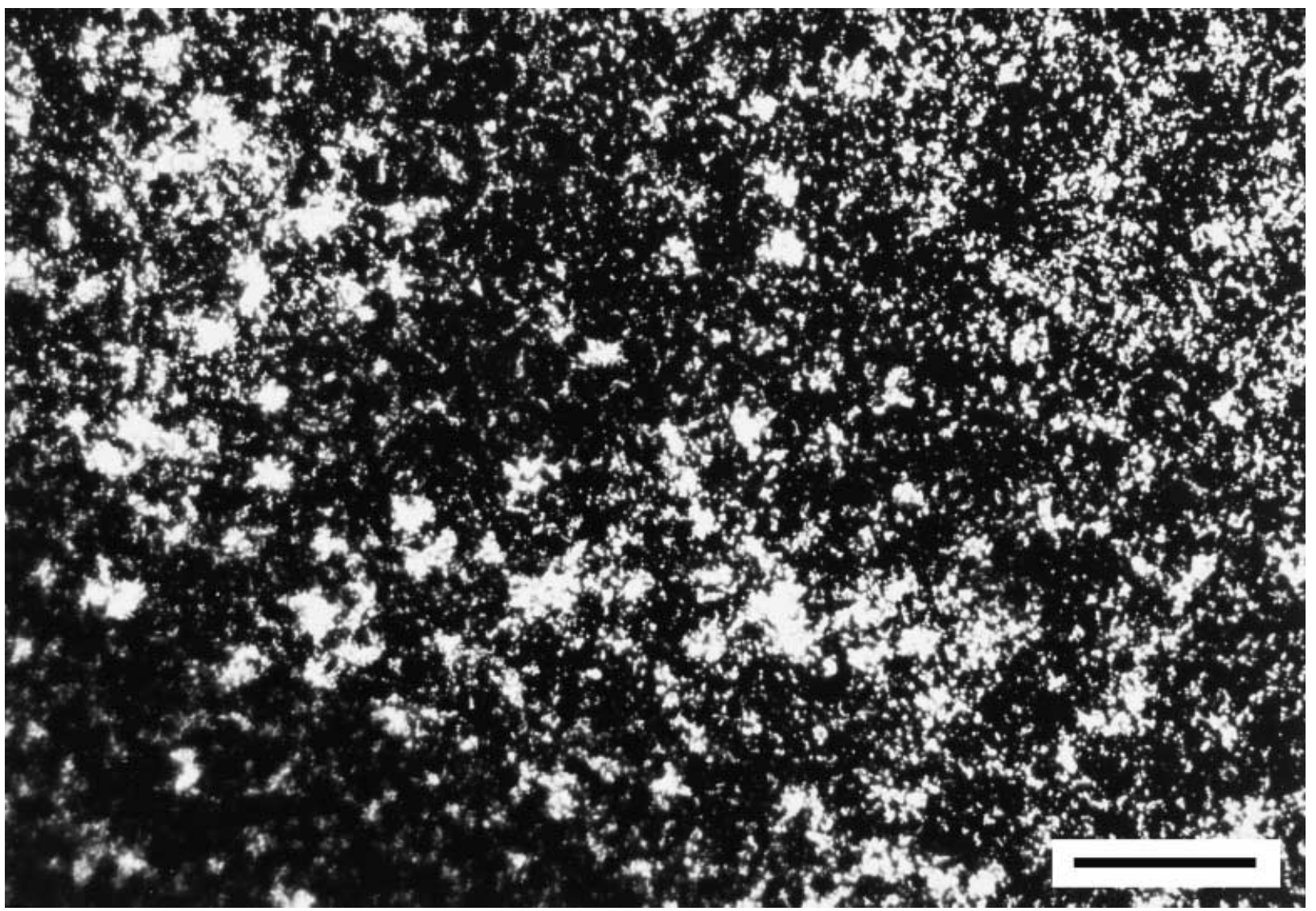

Figure 7 Dark field photomicrograph showing cluster pattern of radiolabelled ligand binding to IGF-II/M6P receptors in myocardium sampled 12 days post-infarct. In bright field photomicrographs (not shown), clusters are seen to be over macrophages in both viable and necrotic tissue. Scale bar $=50 \mu \mathrm{m}$.

We conclude that, following MI, surviving cardiomyocytes at the infarct border show marked changes in IGF-I localization, production and specific binding, with parallel changes in IGFBP-2. Based on our findings, we propose that the IGF axis is directly involved in the events following MI, most likely in an attempt to maintain cardiac function by the induction of hypertrophy to compensate for lost muscle tissue. Alternatively, there have been many reports in recent literature of apoptosis of cardiomyocytes following MI (Olivetti et al. 1994, Sharov et al. 1996, Li et al. 1997, Saraste et al. 1997), particularly in the viable proximal tissue, and we postulate that the increased levels of IGF-I and IGF-I receptor may be a cardioprotective response to minimize apoptotic cell death.

Finally, the dogma that cardiomyocytes are terminally differentiated has recently been challenged (Anversa et al. 1996). Our finding of IGFBP-2 in an area where cardiomyocytes are under the greatest stress may be evidence that these cells can, under certain circumstances, re-enter the cell cycle, since IGFBP-2 transcripts have recently been detected in proliferating myoblasts, but were found to be absent in quiescent and differentiated cells (Rousse et al. 1998). The findings of Reiss et al. (1997) link the IGF-I receptor and its ligand to the re-entry of adult ventricular myocytes into the cell cycle following MI, leading to de novo DNA synthesis, and we speculate that the changes which we observed in the IGF axis may be linked to this function of IGF-I. These diverse roles which we have proposed for the IGF axis are not mutually exclusive.

\section{Acknowledgements}

This study was supported by grants from Medlab, Hamilton, the Waikato Medical Research Foundation and the Laugesen Trust. We thank Ross Lasenby and Trevor Watson for their invaluable assistance with animal care.

\section{References}

Adams GR \& Haddad F 1996 The relationships among IGF-I, DNA content, and protein accumulation during skeletal muscle hypertrophy. Journal of Applied Physiology 81 2509-2516. 
Anversa P, Beghi C, Kikkawa Y \& Olivetti G 1986 Myocardial infarction in rats. Infarct size, myocyte hypertrophy and capillary growth. Circulation Research 58 26-37.

Anversa P, Kajstura J, Cheng W, Reiss K, Cigola E \& Olivetti G 1996 Insulin-like growth factor-I and myocyte growth: the danger of a dogma. Part 1. Postnatal myocardial development: normal growth. Cardiovascular Research 32 219-225.

Bitterman PB, Wewers MD, Rennard SI, Adelberg S \& Crystal RG 1986 Modulation of alveolar macrophage-driven fibroblast proliferation by alternative macrophage mediators. Journal of Clinical Investigation 77 700-708.

Cheng W, Li B, Kajstura J, Li P, Wolin MS, Sonnenblick EH, Hintze TH, Olivetti G \& Anversa P 1995 Stretch-induced programmed myocyte cell death. Journal of Clinical Investigation 96 2247-2259.

Cheng W, Kajstura J, Nitahara JA, Li B, Reiss K, Liu Y, Clark WA, Krajewski S, Reed JC, Olivetti G \& Anversa P 1996a Programmed myocyte cell death affects the viable myocardium after infarction in rats. Experimental Cell Research 226 316-327.

Cheng W, Reiss K, Li P, Chun MJ, Kajstura J, Olivetti G \& Anversa P 19966 Aging does not affect the activation of the myocyte insulin-like growth factor-I autocrine system after infarction and ventricular failure in Fischer 344 rats. Circulation Research $\mathbf{7 8}$ 536-546.

D’Ambrosio C, Valentinis B, Prisco M, Reiss K, Rubini M \& Baserga R 1997 Protective effect of the insulin-like growth factor-I receptor on apoptosis induced by okadaic acid. Cancer Research $\mathbf{5 7}$ 3264-3271.

Dennis PA \& Rifkin DB 1991 Cellular activation of latent transforming growth factor- $\beta$ requires binding to the cationindependent mannose 6-phosphate/insulin-like growth factor type II receptor. Proceedings of the National Academy of Sciences of the USA 88 580-584.

D'Ercole AJ, Stiles AD \& Underwood LE 1984 Tissue concentrations of somatomedin C: further evidence of multiple sites of synthesis and paracrine or autocrine mechanisms of action. Proceedings of the National Academy of Sciences of the USA 81 935-939.

D'Mello SR, Galli C, Ciotti T \& Calissano P 1993 Induction of apoptosis in cerebellar granule neurons by low potassium: inhibition of death by insulin-like growth factor-I and cAMP. Proceedings of the National Academy of Sciences of the USA 90 10989-10993.

Donahue TJ, Dworkin LD, Lango MN, Fliegner K, Lango RP, Benstein JA, Slater WR \& Catanese VM 1994 Induction of myocardial insulin-like growth factor I gene expression in left ventricular hypertrophy. Circulation 89 799-809.

Elliott JL, Oldham JM, Ambler GR, Bass JJ, Spencer GS, Hodgkinson SC, Breier BH, Gluckman PD \& Suttie JM 1992 Presence of insulin-like growth factor-I receptors and absence of growth hormone receptors in the antler tip. Endocrinology 130 2513-2520.

Factor SM, Sonnenblick EH \& Kirk ES 1978 The histologic border zone of acute myocardial infarction - islands or peninsulas? American Journal of Pathology 92 111-124.

Factor SM, Okun EM \& Kirk ES 1981 The histological lateral border of acute canine myocardial infarction. Circulation Research $\mathbf{4 8}$ 640-649.

Ghahary A, Shen YJ, Nedelec B, Scott PG \& Tredget EE 1995 Enhanced expression of mRNA for insulin-like growth factor-I in post-burn hypertrophic scar tissue and its fibrogenic role by dermal fibroblasts. Molecular and Cellular Biochemistry 148 25-32.

Harada M, Itoh H, Nakagawa O, Ogawa Y, Miyamoto Y, Kuwahara K, Ogawa E, Igaki T, Yamashita J, Masuda I, Yoshimas T, Tanaka I, Saito Y \& Nakao K 1997 Significance of ventricular myocytes and nonmyocytes interaction during cardiocyte hypertrophy. Circulation 96 3737-3744.

Hossenlopp P, Seurin D, Segovia-Quinson B, Hardouin S \& Binoux M 1986 Analysis of serum insulin-like growth factor binding proteins using Western blotting: use of the method for titration of the BPs and competitive binding studies. Analytical Biochemistry 154 $138-1430$.

Ito $\mathrm{H}$, Hiroe M, Hirata Y, Tsujino M, Adachi S, Shichiri M, Koike A, Nogami A \& Marumo F 1993 Insulin-like growth factor-I induces hypertrophy with enhanced expression of muscle specific genes in cultured rat cardiomyocytes. Circulation 87 1715-1721.

Kajstura J, Cheng W, Reiss K, Clark WA, Sonnenblick EH, Krajewski S, Reed JC, Olivetti G \& Anversa P 1996 Apoptotic and necrotic cell deaths are independent contributing variables of infarct size in rats. Laboratory Investigation 74 86-107.

Krishnamurthi R, Maxwell L, Bassett NS, Gavin JB, Gluckman PD \& Johnston BM 1997 The spatial and temporal distribution of insulin-like growth factor-I following experimental myocardial infarction in rats. Cardiac Pathology 6 197-203.

Li F, Wang X, Capasso JM \& Gerdes AM 1996 Rapid transition of cardiac myocytes from hyperplasia to hypertrophy during postnatal development. Journal of Molecular and Cellular Cardiology 28 $1737-1746$

Li Q, Li B, Wang X, Leri A, Jana KP, Liu Y, Kajstura J, Baserga R \& Anversa P 1997 Overexpression of insulin-like growth factor-I in mice protects from myocyte death after infarction, attenuating ventricular dilation, wall stress and cardiac hypertrophy. Journal of Clinical Investigation 100 1991-1999.

McCusker RH, Busby WH, Dehoff MH, Camacho-Hubner C \& Clemmons MH 1991 Insulin-like growth factor (IGF) binding to cell monolayers is directly modulated by the addition of IGFbinding proteins. Endocrinology 129 939-949.

Mallory GK, White PD \& Salcedo-Salgar J 1939 The speed of healing of myocardial infarction. American Heart Journal 18 647-671.

Nagaoka I, Someya A, Iwabuchi K \& Yamashita T 1991 Expression of insulin-like growth factor-IA and factor-IB mRNA in human liver, hepatoma cells, macrophage-like cells and fibroblasts. FEBS Letters $28079-83$.

Olivetti G, Capasso JM, Meggs LG, Sonnenblick EH \& Anversa P 1991 Cellular basis of chronic ventricular remodeling after myocardial infarction in rats. Circulation Research 68 856-869.

Olivetti G, Quaini F, Sala R, Lagrasta C, Corradi D, Bonacina E, Gambert SR, Cigola E \& Anversa P 1994 Acute myocardial infarction in humans is associated with activation of programmed cell death in the surviving portion of the heart. Journal of Molecular and Cellular Cardiology 28 2005-2016.

Palacios JM \& Dietl MM 1987 Regulatory peptide receptors: visualization by autoradiography. Experientia 43 750-761.

Parry AL, Nixon AJ, Craven AJ \& Pearson AJ 1995 The microanatomy, cell replication, and keratin gene expression of hair follicles during a photoperiod-induced growth cycle in sheep. Acta Anatomica 154 283-299.

Rechler MM \& Nissley SP 1985 The nature and regulation of the receptors for insulin-like growth factors. Annual Review of Physiology 47 425-442.

Reiss K, Kajstura J, Capasso JM, Marino TA \& Anversa P 1993 Impairment of myocyte contractility following coronary artery narrowing is associated with activation of the myocyte IGF-I autocrine system, enhanced expression of late growth related genes, DNA synthesis, and myocyte nuclear mitotic division in rats. Experimental Cell Research 207 348-360.

Reiss K, Kajstura J, Zhang X, Li P, Szoke E, Olivetti G \& Anversa P 1994a Acute myocardial infarction leads to upregulation of the IGF-I autocrine system, DNA replication, and nuclear mitotic division in the remaining viable cardiac myocytes. Experimental Cell Research 213 463-472.

Reiss K, Meggs LG, Li P, Olivetti G, Capasso JM \& Anversa P $1994 b$ Upregulation of IGF-I, IGF-I receptor, and late growth related genes in ventricular myocytes acutely after infarction in rats. Journal of Cellular Physiology 158 160-168. 
Reiss K, Cheng W, Pierzchalski P, Kodali S, Li B, Wang S, Liu Y \& Anversa P 1997 Insulin-like growth factor-I receptor and its ligand regulate the reentry of adult ventricular myocytes into the cell cycle. Experimental Cell Research 235 198-209.

Resnicoff M, Abraham D, Yutanawiboonchai W, Rotman HL, Kajstura J, Rubin R, Zoltick P \& Baserga R 1995 The insulin-like growth factor-I receptor protects tumor cells from apoptosis in vivo. Cancer Research 55 2463-2469.

Rodriguez-Tarduchy G, Collins MK, Garcia I \& Lopez-Rivas A 1992 Insulin-like growth factor-I inhibits apoptosis in IL-3-dependent hemopoietic cells. Journal of Immunology 149 535-540.

Rousse S, Montarras D, Pinset C \& Dubois C 1998 Up-regulation of insulin-like growth factor binding protein-5 is independent of muscle cell differentiation, sensitive to rapamycin, but insensitive to wortmannin and LY294002. Endocrinology 139 1487-1493.

Saraste A, Pulkki K, Kallajoki M, Henriksen K, Parvinen M \& Voipio-Pulkki L-M 1997 Apoptosis in human acute myocardial infarction. Circulation 95 320-323.
Scheven BA \& Hamilton NJ 1991 Stimulation of macrophage growth and multinucleated cell formation in rat bone marrow cultures by insulin-like growth factor-I. Biochemical and Biophysical Research Communications 174 647-653.

Sharov VG, Sabbah HN, Shimoyama H, Goussev AV, Lesch M \& Goldstein S 1996 Evidence of cardiomyocyte apoptosis in myocardium of dogs with chronic heart failure. American Journal of Pathology 148 141-149.

Teiger E, Dam T-V, Richard L, Wisnewsky C, Tea B-S, Gaboury L, Tremblay J, Schwartz K \& Hamet P 1996 Apoptosis in pressure overload-induced heart hypertrophy in the rat. Journal of Clinical Investigation 87 2891-2897.

Venkatesan N \& Davidson MB 1990 Insulin-like growth factor I receptors in adult rat liver: characterization and in vivo regulation. American Journal of Physiology 258 E329-E337.

Received 18 May 1999

Accepted 29 July 1999 